\title{
Developing Students Essay Writing
}

\author{
Mohammad Rajab Hajeid ${ }^{1}$ \\ ${ }^{1}$ Department of English Language, Literature and Translation, Zarqa University, Zarqa, Jordan \\ Correspondence: Mohammad Rajab Hajeid, Department of English Language, Literature and Translation, Zarqa \\ University, Zarqa, Jordan
}

Received: October 1, 2018 Accepted: November 13, 2018 Online Published: November 16, 2018

doi: 10.5539/elt.v11n12p101 URL: https://doi.org/10.5539/elt.v11n12p101

This research is funded by the Deanship of Scientific Research at Zarqa University-Jordan

\begin{abstract}
This paper tries to shed light on the use and endeavors teachers bear in correcting students writing papers without achieving good results to improve their writing.

This theoretical research or reflection of this paper attempts to explore the reasons why some teachers sometimes feel that their teaching of writing is worthless since they spend a lot of time commenting and writing marks on students corrected papers and still many students do not get better or improved.
\end{abstract}

Keywords: correcting students' writing, improve, and individual paper

\section{Correcting Students Writing Essays}

Teachers usually spend a lot of time correcting student's writing papers and giving Credential notes on such papers since they were promised to receive back their papers as soon as possible. So teachers deserve a lot of credit because no doubt they spend a lot of time replying and responding to student writing. Although, long time is spent commenting on each individual paper, the student does not improve. We as teachers write brief notes so that $\mathrm{s} /$ he will not, get worried and do hard works such as, spelling, grammatical and structural mistakes so that he will not have doubts of the corrections.

We also underline and focus on the most important mistakes. Actually, students often give short look at the red marks on his paper, folds the paper and keep it in his pocket or in one of his books and never looks at it again. So they are careless about the comments.

The teaching of composition writing in EFL /ESL classes has long depended on paragraph writing as the primary rhetoric al unit. Robinett (1978) reflects this orientation when she indicated that "students must learn to follow the general rhetorical principles typical of English composition which include the logical organization of sentences within paragraphs, the linking of sentences within paragraphs, and the organization of whole compositions".

When correcting student paragraph writing texts, some teachers dwell and rely heavily on teaching grammar rather than relying on the content of the text (Larsen, 1983). Some teachers tend to impose themselves as authorities and make comments reflecting the application of an ideal standard than having a set of criteria interpret texts correctly, so they end up making comments that are inaccurate, misleading, and inappropriate (Taylor, 1981).

The instructor $<\mathrm{s}$ inconsistencies and inaccuracy creates hard difficulties to the learners to realize their major errors. It is discovered in research that teachers are occupied by language specific mistakes in accuracy and incorrectness of EFL /ESL (Sommers, 1980; Tylor, 1981; Raimes, 1983).

\section{Toward More Effective Correction}

Making mistakes is a part of learning, correction is a part of teaching. The teacher does not need to correct the mistakes immediately, but show that a mistake has been made. Then, he gives the student time enough to recognize the mistake and correct it. Most teachers would agree that writing accuracy is most important for our learners when they are practicing carefully something that has just been returned to them as a revisit marking their writing and changing their behavior so that students can understand our notes. 
We have to substitute our commenting notes by adopting a standard that takes into account our student major level of writing standard that takes into consideration student level and ability. After explaining to students the importance of writing multiple drafts. Another learner corrects his last draft. Both learners are involved in writing. Then, students become used to the idea that they can learn from each other as peer correction.

\section{Some Guidelines to Follow When Correcting Students" First Draft}

First-the teacher must focus his attention on the content rather than the mistakes themselves. The student has to rewrite grammar, spelling, and the wrong words that help the teacher with the rhetoric construction as an important part of writing which is often ignored by English teachers (Young, 1978).

NEXT, the teacher needs to arrange pair and group working way that will suit the local situation. He makes sure that the students are working but he does not errors. The student will be deleting, adding, and rewriting a great deal of the essay. On the other hand, focusing interrupt their work and moves round the class and makes notes of the important mistakes. Then, the teacher can help students by supplying words, or rewriting something to make it clear as long as this is done in a natural and relaxing way. One of the leaders who is a good student can also act as an observer to note mistakes for general discussion.

After then, the teacher should take notes of the strong and weak sides of the students accomplished writing. However, teachers should not let students errors distract their positive commenting on students writing within their potential capabilities. It is easier for the teacher to know the weak points in a student writing than the strong ones. We as teachers should not forget to be fair to our students by getting involved in taking notes of the strong and weak sides of their writing. When we correct the second draft of the students writing, we have to take into account other points of view towards this as follows:

Teachers do not need to correct grammar or vocabulary themselves. They have to point the errors so that the students themselves can make the corrections.

Literature revealed that corrections have shown inefficiency of learning writing (Crder, 1967; Gorbet, 1974). On the contrary of that some ways of teaching with different titels such as, Direct method, Natural Approach and Discovery Approach are more fruitful in this matter.

Such methods encourage students to be aware aware of the kinds of errors and make inference about the foreign language by figuring out the rules themselves (Larsen, 1982; Hendrickson, 1976) instead of explaining the rules by the teacher, and have them correct their own mistakes with the use of a dictionary or a grammar book.

Teachers should show students how to deal with the dictionary process and receive feed back to achieve better results. When teachers mark all the mistakes, it becomes something overwhelming to the students, and have proven ineffective, many teachers and educators accept a wide margin of errors from the so-called "standard" forms of the language (Corder, 1967; Dulay \& Burt, 1974). So marking every error and mistake to students do not only destroy their confidence but it will prevent them to learn from their own mistakes according to the Direct and Audio Lingual methods.

The teacher should decide which types of mistakes to correct. Hendrickson (1980) suggested types of errors which hinder communicative performance, and others that have effects on the readers and recurrently happen.

The teachers should diagnose the general problems along with errors that occur on the individual level and try to work on them all. The teachers can also develop the supporting sentences that point grammar and other mechanics. Moreover, the teachers should make a comment, preferably ending the writing process with an overall positive comment to student to be some sort of encouragement.

\section{Teamwork Activities}

In fact, most of the teachers and students consider the teacher himself as the sole provider of the correction process to students writing. On the other hand, some language educators deny the dominant role of the teacher to correct students papers and urge them to adopt the role of being error correctors. Peer correction would help achieving many goals as grammatical and lexical errors. It helps students to recognize content problems as well as organization, development of ideas, and clarity of writing. Wingfield (1997) indicated that research supports self-correction in grammar and lexical errors.

Teachers can use workshops by putting students in groups of three or four and exchange drafts for correction by putting notes and suggestions from peer-corrections which is very helpful. In doing so, every student would receive feedback from the teacher and students on their language use. This is all done as part of a team work in cooperative collaborative sitting. In a short time about 10-20 minutes, they can discuss the weaknesses and strong points of their first copy draft and write notes with comments for discussion in classroom. 
However, teachers may ask whether the students are qualified enough to address the necessary questions, and locate problem areas to give feedback to their friends drafts and assign the weak and strong areas of their writings along with their errors. For students who are unfamiliar with this type of group discussions, the teacher may give a hand out of questions sheet for them to answer in response to the draft paper they are correcting. For example, while they are valuing a draft, they can answer questions regarding the following points, such as:

1) Whether the introduction draws your attention or not, if yes, how? If no, why?

2) Is there a thesis statement? If yes, what is it?

3) Whether the topic sentences are supported by either examples, illustrations, facts, details or anecdotes.

4) Are there conjunctions, coordinators among sentences in each paragraph?

5) Are there transitions between paragraphs?

Are there irrelative sentences within paragraphs? (Oshima, Alice, Hogue, \& Ann, 2007).

In the second draft for language screening, after students have underlined the errors, they may write notes if possible to indicate the kind of mistakes they have committed such as, syntax, tenses, spelling, sentence structure and word choice. At the end, students may be asked to briefly write the types of comprehensive errors committed as final comment with positive recommendations.

In case, students find it vague to understand what is required from them to assign such mentioned errors, it is possible to high light some general grammatical errors within their specific details and assign some of the errors as shown in essay writing for example, as the following: (the correction is between two brackets).

1) Verb tense errors: I never work as a cashier had never worked

2) Verb form errors: Her voice is irritated (irritating) 2

3) Word order: Friday always our busiest night (is) 3

4) Un necessary word: My boss she watches ever one all the time (she)

5) Wrong word choice: The food is delicious .Besides, the restaurant is always crowded (therefore,)

6) Errors in prepositions: We start serving dinner $6 \mathrm{pm}$. (at)6

7) Errors in articles: Dinners expect - glass of water when they sit down at -table (a,the )

8) Other common errors: capitalization, spelling word missing, punctuation, pronouns, etc....)

Teachers can also add other questions which check student's awareness of the vocabulary whether they are specific, advanced or too simple and ask students to give examples about them as well as other sentence fragment in the text which is either complete paragraphs or they do not belong to the main text by diverging from the main thesis statement.

The teacher can help students to a reasonable extent to be as evaluators depending upon how much they can comprehend in their revising and editing tasks, how ready they are to come near such errors and be familiar with the evaluation process, s/he can give them a model of correcting test and writing every student comments on it. The students can evaluate cooperatively in groups with the teacher going over their editing papers and answering questions and offering assistance to each group. In doing so, the teacher gives students a chance to do this task on their own avoiding disordered and unguided editing.

\section{Parallel Writing and Correction}

The teacher can give advice on the students composition writing by following parallel writing as (Harmer, 2001) indicated how to teach English. So students follow closely a model that they were taught which guides their exerted efforts. It is beneficial for the type of formulaic writing usually represented by postcards, certain kinds of letters, announcements and invitations. Then in correcting such writing (Harmer, 2001) thinks that learners find it fruitful especially when they get a certain written work back and improve their terrible English writing which is full of mistakes. In this case, overcorrection can have very unmotivating effect.

As with other ways of correction, the teacher has to balance between accuracy and being sensitive with students to avoid hurting their feelings. The teacher has to avoid over correction. S/he can tell them that they going just to correct their mistakes in spelling, punctuation and grammar.

Another way as a technique which many teachers may use is to reach a consensus on a list of symbols as ( $\mathrm{S}=$ spelling, $\mathrm{WO}=$ word order, $\mathrm{G}=$ grammar...etc.) When students find an error, they can underline it and use a symbol in the margin of the paper to make it less damaging to their psychology by just using the red mark 
approach which is unfavorable to students especially if it is compared to other way of criticism. Most importantly, this technique of correction is one of way of communication. The student has no chance to question it or disagree with. Instead as Harmer (2001) clarified that it is worth writing a note at the end of a written work-anything from "well done" to this is a good work ,but it is worth to look again at your use of past tenses see $\mathrm{x}$ grammar book on page 00 .

However, talking to students about their corrected written works is the solution in this issue. Correction becomes worthless if students put their writing away and never look at it again. So, they are required to redraft their written work again. Then, it would be very beneficial to make a one to one conversation with students after finishing the first draft about every paper and go over their errors as oral feed back with the final written comments on the paper. Once again a teacher may adopt the role of a guide who gives directions and makes recommendations, and gives the choice for the students to take chance without interfering in their point of views regarding their ways of thinking and writing accuracy.

\section{Conclusion}

Writing a text is not an easy task for students as some teachers think. It causes problems for native speakers themselves since it has many problem features as grammar, mechanics, organization, word choice and syntax. So, if writing is a difficult complex process, it will be much more difficult for foreign language learners to learn. In addition to that, there are difficulties in responding to students writing and designing new writing courses to our students since they will be teachers of English later on. They do not only read to write effectively but also they need to receive correct advice.

Nurdan (1995) considered the difficulty of teaching writing comes from the following:

1) The difficulty of the writing process itself.

2) The teaching of writing itself.

3) The teaching of writing to teachers of English themselves.

We learn and teach from a reciprocal role between teachers and learners as (Muray, 1982) reiterated "we can learn to teach at the level where the student is, not where the teacher wishes the student was".

\section{References}

Corder, S. (1967). The Significance of Learner's Errors. International Review of Applied Linqistics, 5, 161-70. https://doi.org/10.1515/iral.1967.5.1-4.161

Dulay, H. C., \& Marina, B. (1974). Errors and strategies in child second language acquisition. TESOL Quarterly, 8, 129-34. https://doi.org/10.2307/3585536

Gorbet, F. (1974). Error analysis - What the teacher can do: A new perspective (pp. 100-193). Ottawa: Research Division, Public Service Commission of Canada.

Harmer, J. (1988). The Practice of English Language Teaching. Longman New York.

Harmer, J. (2001). How to teach English: An introduction to the practice of language teaching. Longman New York .

Hindrickson, J. M. (1976). Effects of error correction treatments upon a language and accurate communication in written compositions of adult learners of English as a second language. Unpublished ph.D DISSERTATION, The Ohio State University.

Larsen-Freeman, D. (1986). Techniques and Principles in Language Teaching. Oxford University Press.

Murray, D. M. (1982). Writing as a process: How writing finds its own meaning in Eight approaches to teaching composition. In T. R. Donovan, B. W. Maclelland (Eds.). National Council of Teachers of English.

Nurder, O. (1995). English Teaching Forum. TESOL, 33(1).

Oshima, A., \& Hogue, A, (2007). Writing Academic English (3rd ed). Oxford University Press.

Raimes, A. (1983). Techniques in Teaching writing. New York: Oxford University Press.

Robinett, B. W. (1978). Teaching English to speakers of other languages. Minneapolis: University of Minnesota Press.

Sommers, N. (1980). Revision strategies of student writers and experienced adult writers. College Compositions and Communications, 31, 378-88. https://doi.org/10.2307/356588

Taylor, B. (1981). Content and Written form : A two way street. TESOL Quarterly, 15, 5-13. https://doi.org/10.2 


\section{$307 / 3586368$}

Wingfield, R. J. (1975). Five Ways of dealing with errors in written compositions. English Language Teaching Journal, 29, 311-313. https://doi.org/10.1093/elt/XXIX.4.311

Young, R. E. (1978). Paradigms and Problems: Needed research in rhetorical invention. In Research on composing. In C. Cooper, \& L. Odell (Eds.). Urbana .Ill: National Council of Teachers of English.

\section{Copyrights}

Copyright for this article is retained by the author(s), with first publication rights granted to the journal.

This is an open-access article distributed under the terms and conditions of the Creative Commons Attribution license (http://creativecommons.org/licenses/by/4.0/). 